\title{
Ras-Related Protein Rab-27A
}

National Cancer Institute

\section{Source}

National Cancer Institute. Ras-Related Protein Rab-27A. NCI Thesaurus. Code C119636.

Ras-related protein Rab-27A (221 aa, $\sim 25 \mathrm{kDa}$ ) is encoded by the human RAB27A gene.

This protein plays a role in the exocytosis of cytotoxic granules from lymphocytes. 